\title{
Application of E-Learning and Artificial Intelligence in Education Systems in Indonesia
}

\author{
Dardya Putra Hastungkara \\ Faculty of Social Science and \\ Political Science, \\ University of Indonesia, \\ Depok, Indonesia
}

\author{
Endah Triastuti \\ Faculty of Social Science and \\ Political Science, \\ University of Indonesia, \\ Depok, Indonesia
}

\begin{abstract}
Technology movement creates progressive impacts towards the development of communication network, computer, and the Internet. An innovation that is known as Artificial Intelligence (AI,) is one of many products. The usage of AI technology is predicted to expand globally, including in Indonesia. The influence of AI technology on improving the effectiveness of eLearning concepts enables integration into the advancement of the education system in Indonesia. This study aims to explore the potential and impact of applying AI technology in eLearning, and the readiness of various factors that influence the education system and Information and Communication Technology (ICT) in Indonesia. The discussion is based on secondary data and comprehensive observations of the prevailing learning structure.
\end{abstract}

\section{Keywords}

e-Learning, Artificial Intelligence, Information and Communication Technology, Education, Indonesia

\section{INTRODUCTION}

Globalization plays an important role, including developments in the field of information and communication technology in Indonesia. Along with these developments, computer systems and networks have also increased, making the

role of the Internet a vital media for information and communication. The existence of the Internet is no longer just an option but an important part of life. Along with the changing times and needs, the challenges in the education sector are increasingly greater to prepare students who are able to compete in the global arena. However, with increasing challenges, the world of education in Indonesia still has many obstacles.

Education in Indonesia faces several major problems related to access and quality. Only about half of the eligible children are enrolled at the junior secondary level and only one third at the senior secondary level. Regarding quality, most students fail to meet the passing grade scores in various subjects at all levels on the final school exam. Information and communication technology is seen as a potential contributor to solutions to this problem. The success of information technology depends on the availability of the right infrastructure. According to Asosiasi Penyelenggara Jasa Internet Indonesia or APJII (Indonesian Internet Service Providers Association), in 2017, 104.96 million people accessed the internet in Indonesia. This figure is projected to grow to 133.39 million by 2021 . Other statistics show that information and communication technology infrastructure is less extensive compared to neighboring countries such as Singapore, Malaysia, and Thailand. In addition, the cost of internet access is still quite expensive in Indonesia. The application of e-Learning in Indonesia can be seen as a complement or substitute for the traditional learning - teaching process. According to Oemar Hamalik (1980), media are tools, methods and techniques used in order to make communication and interaction more effective between teachers and students in the education and teaching process. E-Learning is one of many forms of media that can facilitate and optimize the teaching-learning process in the education system in Indonesia. Law of Republic of Indonesia No. 20 of 2003 concerning the National Education System, Article 31 states: distance education functions to provide educational services to groups of people who cannot attend face-to-face or regular education; distance education is held on all lines, levels and types of education; distance education is carried out in various forms, modes and scope supported by learning facilities and services as well as an assessment system that ensures the quality of graduates in accordance with national education standards, and; forms of distance education include written education programs, radio, audio or video, television, and computer-based media.

Accordance with the law, there are a number of subjects from the High School and Vocational High School that have been developed e-Learning as a substitute for face-to-face teaching. At tertiary education level, most universities in Indonesia have implemented e-Learning, especially as support for their learning and teaching process. In its expansion, the Ministry of National Education has tested Open Middle Schools in seven districts in six provinces by implementing e-Learning.

In its implementation, there are several obstacles that prevent further e-Learning applications. One of them is infrastructure that does not support learning activities. Of the 267 million people, only 27 million have fixed telephone facilities, a prerequisite for accessing distance e-learning facilities. Using a cellphone for an internet connection is not possible because of high costs, and on the other hand Internet customers in Indonesia are limited. Although the majority of e-learning operators are higher education institutions, there are no standards in their content that do not always reach academic intellectual standards. Then, there is no structured and comprehensive coordination in implementing e-Learning. In certain universities, each department builds its own e-Learning facilities without disrupting the efforts of other departments, especially at the national level. Communities in Indonesia generally prefer to speak verbally rather than write, and prefer to attend teaching and learning activities rather than studying on their own. Therefore, Indonesian students prefer to communicate or interact directly with other students or lecturers rather than communicating virtually as is commonly found in e-Learning. So that e-Learning systems can provide optimal benefits in the long run, today a more structured and integrated system design is needed, using the right technology to fulfill its objectives as a learning medium that is able to equip students to compete and remain literate in information technology, by flexible. One of 
them is by utilizing Artificial Intelligence (AI), namely artificial intelligence, which can overcome a number of deficiencies in eLearning and the education system in Indonesia.

\section{E-LEARNING}

One tangible form of utilizing the internet is a distance learning system, which uses electronic media or is called e-Learning. ELearning is one of the systems of the e-Life section, which is a technological related to the life cycle. Based on electronics, eLife enables humans to carry out daily activities through technology assistance. Internet, satellite, or CD-ROMs are some of the various electronic media choices available. Through eLearning, teaching can be delivered at the same and different times (Teahan, 2010). Elliott Masie, Cisco, \& Comellia (2000) argue that e-Learning is a type of learning that can communicate material through electronic media (Internet, Intranet, satellite, TV, CD-ROM). Whereas Martin Jenkins \& Janet Hanson (2003) consider that e-Learning is a learning process that is facilitated by the use of communication information technology to create efficiencies that are not obtained by traditional learning process models.

\section{HISTORY OF E-LEARNING DEVELOPMENT}

The e-Learning program was first introduced by the University of Illinois, Urbana-Champaign in 1990, using a computer-based instruction system, PLATO (Programmed Logic for Automated Teaching Operations).

The program was created for the University of Illinois students, but eventually, the program was used in schools in almost all regions. The first e-learning system really only served to convey information to students (trainees). But as the 70 s entered, elearning began to become more interactive. Universities in the UK really want to use e-learning. Their education system has focused on distance learning.

At that time, the course material delivered by post and communication with the instructor was still in the mail. Whereas with the internet, education is starting to offer a wider range of interactive learning experiences as well as faster communication with students via e-mail.

This is a track record of the development of e-Learning from the beginning of the introduction to finally developing into a webbased application that continues to be used today (Cross, 2002):

Table 1. Development of e-Learning Systems (Source: Cross, 2002)

\begin{tabular}{|c|c|}
\hline 1990 & $\begin{array}{c}\text { This year, e-Learning applications appear in the form of } \\
\text { a stand-alone PC or CD-ROM. The media contains } \\
\text { material in writing or multimedia and uses MOV, } \\
\text { MPEG-1, or AVI formats. Therefore, 1990 was declared } \\
\text { as the era of CBT (Computer Based Training). }\end{array}$ \\
\hline 1994 & $\begin{array}{c}\text { After being well received by the public as a user, CBT } \\
\text { began to be presented in a more attractive form, even } \\
\text { through the mass production process. }\end{array}$ \\
\hline
\end{tabular}

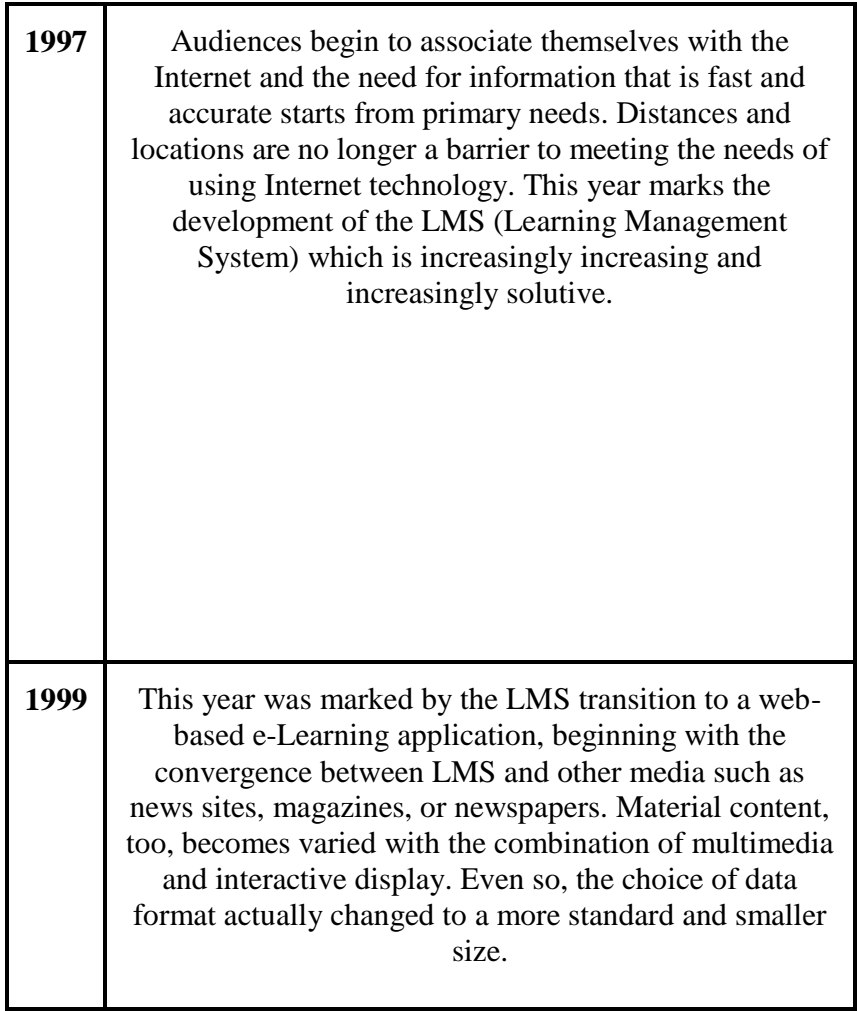

\section{FUNCTIONS AND BENEFITS OF E- LEARNING}

E-Learning is a modern activity process because it uses computer technology, the internet and other digital media, but eLearning activities are not completely separate from traditional learning concepts. E-learning still has traditional values that are very good and will continue to be maintained in the application process. This is confirmed by research conducted by Siahaan (2002), there are three functions of electronic learning in traditional learning activities or in the classroom:

Table 2. e-Learning Function (Source: Siahaan, 2002)

\begin{tabular}{|c|c|c|}
\hline Substitution & Complement & Supplements \\
\hline $\begin{array}{l}\text { E-learning is } \\
\text { useful as a } \\
\text { substitute for } \\
\text { learning when in } \\
\text { class if students } \\
\text { cannot attend or } \\
\text { are absent. In } \\
\text { practice, e- } \\
\text { Learning does not } \\
\text { require direct } \\
\text { face-to-face } \\
\text { processes as is } \\
\text { always applied in } \\
\text { class. }\end{array}$ & $\begin{array}{l}\text { E-Learning works } \\
\text { as a complement. } \\
\text { Unavailable } \\
\text { learning material } \\
\text { or has not yet } \\
\text { been delivered in } \\
\text { the classroom, } \\
\text { can be d istributed } \\
\text { through electronic } \\
\text { media such as } \\
\text { CDs or flash disks } \\
\text { given to students. }\end{array}$ & $\begin{array}{c}\text { In some } \\
\text { conditions, } \\
\text { teacher needs } \\
\text { additional } \\
\text { material as a } \\
\text { supplement for } \\
\text { students. } \\
\text { Traditional } \\
\text { learning systems } \\
\text { are limited by } \\
\text { time, the use of e- } \\
\text { Learning media is } \\
\text { much more } \\
\text { flexible. } \\
\text { Additional } \\
\text { material can be } \\
\text { put into electronic } \\
\text { media. }\end{array}$ \\
\hline
\end{tabular}


E-learning is useful for facilitating the process and continuity of interaction between students and learning material. The teacher or instructor is also given the opportunity to place learning materials as well as assignments in certain documents on the website or other electronic media for later access by students. The benefits of e-Learning, when discussed in more detail, are divided into several categories and divided according to the point of view of students and institutions (instructors). However, the benefits of e-Learning in general will be discussed first (Siahaan, 2002):

\section{- Flexibility}

Learning tools in the e-Learning category free users to choose a time and place to access trips. In addition, the range that is able to be covered is very broad, in contrast to traditional learning which is limited by factors of space or number of students. The e-Learning or online learning room can accommodate large numbers of students without worrying about seating limitations and so on.

\section{- Accessibility}

One of the main keys in e-Learning is the subject matter that is obtained easily and quickly. Almost similar to traditional learning, e-Learning learning also has a curriculum that contains several some many of subject matter that must be understood and mastered as a whole by students. Assisted by technological sophistication, the materials or materials can be downloaded and accessed anytime and anywhere without being limited by time or other factors.

\section{- Independence}

E-Learning patterns and learning systems provide opportunities for students to take control of learning success. Example: individuals who are already working, but wish to continue their education to a higher level. However, because the main activity is to work, the individual cannot attend classes or take part in general lecture activities. E-Learning comes as a solution by providing lecture material online so that it does not require the presence of individuals in the classroom. Individuals, or students, are given the freedom to learn and create indicators of success independently.

\section{- Time and Cost Efficiency}

As discussed earlier, online learning or e-learning is supported by technological sophistication so that it does not require physical facilities in its application except electronic media (computers, tablets, etc.) and can be done anywhere and anytime. These characteristics certainly have a positive impact in increasing cost efficiency for administrators and the provision of facilities (classrooms or transportation).

\section{E-LEARNING POINT OF VIEW}

The benefits of e-Learning fit into 2 types of perspectives:

\subsection{Student}

High learning flexibility is a major benefit that students can immediately feel. According to Brown (2009), the flexibility of e-Learning activities is able to facilitate limitations experienced by students with the following backgrounds:

- Go to school and live in remote areas. E-Learning helps students to follow subjects cannot be provided by their school by providing these materials online and offline.

- Follow a home school or home education program. The patterns offered by the concept of e-Learning can help students learn material that cannot be taught by parents or tutors (such as Foreign Language or Computer Science). E-Learning is basically intended for students who cannot follow the conventional learning system, for example students who drop out of school or fail to qualify for the selection of favorite schools.

\subsection{Teachers}

The benefits of e-Learning are reciprocal, so they are not only felt by students as recipients but also teachers as material providers. Here are some of the benefits teachers receive when implementing e-Learning learning systems (Soekartawi, 2003):

- Access in improving the quality of learning materials in accordance with the demands of scientific development is now easier because it can be done and distributed online and then distributed both online (Internet-based) and offline (Electronic-based).

- More free time for teachers is available so that opportunities for teachers to develop themselves, such as conducting research in order to increase insights which will then affect teaching activities.

- Monitor learning activities online. Although not directly related to the traditional learning system, through the help of technology, teachers can find out when students learn, topics learned, duration of learning will be certain topics, and the number of repetitions in learning the topic through digital data collection. Other activities such as checking whether students have done practice questions and checking students' answers can also be done in the corridor of e-Learning learning.

\section{WEAKNESSES IN THE IMPLEMENTATION OF E-LEARNING}

Apart from the various benefits generated, both for students and educational institutions, found some assessments that are considered lacking of e-Learning as a concept, among others is the reduced interaction between teachers and students or between students. This deficiency can have an impact on the delay in the formation of values in the learning and teaching process. The e-Learning system is also sometimes considered a product of capitalism because it tends to ignore the academic aspects and prioritize business aspects. Students are faced with learning activities based on learning systems, in contrast to traditional learning styles that train students in psychomotor and affective aspects. Lack of workers who have skills in the field of the Internet and computer mastery. Example: teachers, especially in remote areas, are not yet familiar with the mechanism of the Internet so that the learning and teaching process is not conducive. This phenomenon is supported by the fact that not all places or regions provide Internet facilities (the majority are caused by lack of electricity, telephone, or computer) and adequate software (software costs are still relatively expensive at this time). Through e-Learning learning patterns, students are required to learn the material without the presence and assistance of a mentor. This can lead to lazy factors in students because they are not motivated properly.

\section{ARTIFICIAL INTELLIGENCE}

The discussion about e-Learning is inseparable from the smart programs behind it. The smart program is Artificial Intelligence or commonly abbreviated with AI. AI technology is one part of computer science that makes it easy for humans to work. Today, computers are not only used for simple purposes but are expected to be able to do everything that humans can do. In general, AI is a science that is used to imitate the intelligence 
possessed by living things and is applied through machines with the aim of solving a problem. This understanding is supported by a variety of opinions from experts:

- John McCarthy (1960): AI is a computer system that is formed to know and model human thought processes and design machines so they can mimic human behavior.

- Rolston (1988): AI is a computer-based solution to existing problems using applications such as human thought processes.

- Teahan (2010): AI is the science of how to build a computer system that shows intelligence in various ways.

\subsection{Method of Artificial Intelligence}

Besides being a science of computer systems, Artificial Intelligence is also a dynamic study because it covers the science of technology, machinery, algorithms, mathematics, and complex code systems. To run a system with an artificial intelligence program, at least there are several methods applied in its use (Konar, 2005):

1. Fuzzy Logic (FL), which is a technique used to adapt how living things can adjust conditions by providing flexible decisions. The application of fuzzy logic can be done for consideration of uncertain things.

2. Evolutionary Computing (EC). This method applies concepts inspired by biological sciences such as population and mutation to produce the best problem solving.

3. Machine Learning (ML) or machine learning is a technique replacing or imitating human behavior.

\subsection{Application of Artificial Intelligence}

During its development, several applications of Artificial Intelligence in life include the following (Idris, 2012):

Natural Language Processing, where users can communicate with computers using everyday language. Artificial intelligence learns how natural language is processed so that users can communicate with computers. The concentration of this science is the interaction between computers and natural languages used by humans, namely how computers extract information from input in the form of natural or produce output that is also in the form of natural language.

Expert System, namely the field of science that studies computers as a tool for storing the knowledge of experts so that computers have the ability to solve problems by imitating the expertise possessed by experts. The application of this system makes it easy for ordinary people to solve complex problems. According to Turban (1990), an expert system can be displayed with two environments, namely the development environment and the consultation environment (runtime). The development environment is used by ES builders to build components and incorporate knowledge into the knowledge base. The consultation environment is used by non-rooted users to gain expert knowledge and advice. This environment can be separated after the system is complete.
Speech Recognition, which is a technology that is able to read human voices into a command and be understood by computers, so this allows humans to communicate with computers using sound. Examples of speech recognition that has been widely applied at this time are virtual assistant applications on mobile phones or other devices that support these features, including Siri, Cortana, Google Now, and many others.

\subsection{The Purpose of Artificial Intelligence}

The ability to solve a problem is one way to measure the intelligence of a program in various contexts. Measurement of intelligence of a program aims to see the ability of artificial intelligence in helping humans. This intelligence is the ability of the program to learn, understand and comprehend messages, respond quickly to commands, and can solve problems effectively. Some goals of artificial intelligence according to Winston and Prendergast (1984) are: making machines smarter, understanding intelligence, and increasing the benefits of machines.

\subsection{The Advantages of Artificial Intelligence}

According to Kusumadewi (2003), Artificial Intelligence has advantages when compared to intelligence possessed by humans, namely:

1. Permanent: as long as the system and program are not changed, artificial intelligence will not change.

2. Easier to reproduce and spread: easier to move data from one computer to another when compared to sharing knowledge from one human to another.

3. Consistent: artificial intelligence is a consistent computer technology, whereas natural intelligence has a tendency to change.

4. Can be documented: each activity carried out by artificial intelligence can be easily tracked while natural intelligence is difficult to reproduce

5. Able to do work faster and better.

6. The cost is cheaper than bringing in an expert.

\section{RESEARCH METHODOLOGY}

This research uses a qualitative descriptive approach. Qualitative research is research that is used to investigate, discover, describe, and explain the quality or idiosyncrasy of social influence (Saryono, 2010). John W. Creswell (2010) says the purpose of the qualitative inquiry process is to understand social problems or human problems based on the creation of holistic images, which are formed with words, report the views of informants in detail and are arranged in a scientific setting. The paradigm used in this research is constructivist, because reality must be filtered first through the way someone sees something (Morissan, 2009). Data analysis is performed by data reduction, data presentation and conclusion drawing.

\section{APPLICATION OF ARTIFICIAL INTELLIGENCE IN E-LEARNING IN INDONESIA}

As reported on the website of Squline website (www.squline.com), as of 2017 Indonesia has been ranked 8th (eighth) for e-Learning learning on a mondial scope. The results of this research are in line with the Ministry of Research, Technology and Higher Education of the Republic of Indonesia (Kemenristekdikti) who have actively voiced policies, programs 
and views on Indonesia's readiness to face the 4th Globalization of Education and the 4th Industrial Revolution (RI 4.0) since the beginning of the year 2018 .

The Procurement of Education Globalization and RI 4.0 is driven by the urgency of the government to produce a generation of Human Resources (HR) who are competent, innovative, and capable of optimally mastering a field or science. HR with these criteria is considered capable of contributing to national development and helping the process of improving the quality of life. The inclusion of the name of Indonesia in the category of Countries that are ready to carry out the 4th Industrial Revolution according to the report "The Preliminary 4IR Country Readiness Evaluation" increases Indonesia's focus on education infrastructure in the framework of preparation for the 4IR (The Fourth Industrial Revolution). Even so, the impact of the educational revolution felt by developing countries like Indonesia, especially in primitive regions or regions, is not really significant. This is often caused by the relatively low level of competition in the education system in Indonesia. In addition, the stage of the education system in Indonesia still persists in understanding Education 1.0. Utilization of the growing Internet in Indonesia has also not been fully utilized because the majority is still channeled to sustain social activities compared to accessing the development of science and technology.

One of the prominent characteristics of Education 1.0 is that teachers function as the main source in science and technology. Unlike the case with the understanding of teachers in the perspective of Education 4.0; the teacher has the main function as a group leader (team leader) who collaborates with students in creating science and technology through the process of Internetbased learning resources or Artificial Intelligence Portals. In reality, the role of Artificial Intelligence (AI) is indeed inseparable from the corridors of online learning; so that in the successful implementation of e-Learning in Indonesia, constructive changes are needed, one of which is AI technology.

The idea of creating virtual guides and facilitators (able to think, act, react, interact and respond and use verbal and non-verbal communication) for use in educational settings such as eLearning can be a promising development. Although not yet implemented in Indonesia, installation of AI technology in eLearning systems has been implemented in several countries such as the United States. University of Southern California (USC) and the Captivating Virtual Instruction for Training (CVIT) project, for example. CVIT is a learning strategy that aims to integrate traditional methods (learning activities in class) with the most appropriate virtual technology (intelligent tutors, Augmented Reality (AR), etc.) in e-Learning programs.

The idea of virtual facilitators is thought to be able to answer the problem of human resources in Indonesia in terms of quantity (the number of people's interest in the teaching profession is still low) and quality (as previously explained, there are still teachers who have not received maximum education related to the use and application of Internet technology and e-Learning). Not only that, virtual facilitator solutions also address issues related to the culture of education in Indonesia, which are familiar with learning and teaching activities in the classroom. Analog transition to digital certainly raises its own unrest for teachers and especially students. In this case, students are at risk of failing to adapt and lead to rejection of the online learning system. Therefore, the emergence of virtual facilitators with human-like characteristics is expected to be able to create realtime experiences, such as question and answer sessions and so on. E-Learning, too, can be done together collectively through video conferencing applications to further create the 'euphoria' of learning in the classroom.
In addition to making ideas in forming virtual guides and facilitators, the adoption of an adaptive learning environment also drives the success rate of the application of artificial intelligence to e-Learning in Indonesia. One example of eLearning products in Indonesia that implements adaptive learning environments and has been running for a long time is HarukaEdu. As quoted on the Kompasiana website online (www.kompasiana.com), HarukaEdu is a well-known online learning tool in maintaining quality, fixing the cost of proper education, and acting as a partner for individuals who have difficulty in accessing the internet. Besides lectures can be done remotely, users also get free online courses or training courses through collaboration with several universities in Indonesia.

Further discussion about Machine Learning and AI in eLearning is inseparable from the several advantages it can offer. The application of AI in e-Learning content opens up new ways of looking at learning itself. Everyone learns differently, and follows different steps, so one of the main challenges in teaching and learning activities in general is to maintain a balance between involving students who are faster and accommodating those who are slower. AI in situations like this, creates an adaptive learning environment so that it allows the pace of learning to adjust to each individual. This includes environments that can accommodate individual learning styles and run in parallel, with each other. E-Learning content can also be adjusted based on past performance and learning objectives of each student so that each student can gradually collect the building blocks needed by each skill, for example: a student who completes the module faster will then be given material with an approach more comprehensive, whereas students who lack basic knowledge will be given linear modules. Creating a learning environment that is far more effective and increases the likelihood of a group of individuals assimilating information accurately within a certain period of time. Apart from the quality of learning, AI presents a very valuable solution for e-Learning in the world of education with a high level of dynamics. An eLearning system that needs to update their subject matter continuously will benefit from an adaptive learning environment because Machine Learning has the ability to accurately predict how subject matter needs to be updated and changed, by analyzing data to be personalized. Adaptive learning technology will create an environment that is fully adapted to content that is not only changing but is also made based on the needs of students or individuals. Thus, the use of this technology will greatly improve the quality of education received by students. In addition, the application of the Machine Learning concept to eLearning is closely related to the allocation of resources. With a lack of quantity and uneven human resources throughout Indonesia, in this case teachers, students who use e-Learning as a complement can receive the online resources they need to support learning materials, in accordance with their interests and academic goals. This personalization feature can also give students additional motivation and ease to reach their potential.

\section{INDONESIA'S READINESS FOR THE IMPLEMENTATION OF ARTIFICIAL INTELLIGENCE IN E-LEARNING}

E-learning is one of the interesting digital learning media because of the ease of access that is not limited by time and place. Increasingly high user interest is faced by various obstacles in terms of infrastructure, resources, access to information, government support and policies, technological advances, and the culture of the people therein. Also beside, the factors that move students towards e-Learning education need to be carefully understood. Different student characteristics in each country certainly have their way of responding to various 
knowledge-oriented initiatives. Therefore, studies of readiness for the application of Artificial Intelligence in e-Learning must consider the specific influence on each situation, institution or learning program. Although various factors influence implementation and effectiveness, readiness is a critical success factor. In addition, the readiness of integration both involves many components including students, instructors, technology, and the environment, which must be prepared to formulate a coherent and achievable strategy. The level of readiness for implementing AI in e-Learning can help education stakeholders to design and adjust resources, as well as direct the national government to formulate a comprehensive strategy for overcoming challenges and implementing objectives effectively.

E-learning is a learning center that is student-centered, so the main focus is to divert learning activities in Indonesia from passive to active mode. Students become the core players in the e-Learning learning process, especially with the use of AI that requires the active role of its users to work optimally. Strengthening the learning model is needed through material enrichment and development of educational technology, so that there will be a shift in the role of teachers who are no longer the main source of information, but rather the active role of students themselves (Education 4.0). At this time, Indonesia still needs technical training for teachers to get direction and debriefing, so they can understand their role as facilitators, collaborators, mentors, trainers and study partners for students in the elearning process that is carried out.

In implementing $\mathrm{AI}$ as a e-learning, teachers as facilitators are required to have some basic competencies, namely: the ability to make instructional designs, learning according to pedagogical rules, and mastery of ICT, namely the use of the internet as a source of learning in order to obtain the latest and quality teaching material, and mastery of learning materials according to their expertise (Sutrisno, 2007). Various counseling, seminars, workshops, and technical guidance related to the application of e-Learning learning can be held in educational institutions, and also discussion forums through various media so that teachers can exchange ideas or experiences. Also besides, infrastructure in Indonesia is still inadequate in facilitating the needs of the latest AI technology. The government needs to improve facilities and infrastructure that support e-Learning learning to be effective. These components include the reach of electricity to the region, fast internet connection, and computers with the latest systems provided at educational institutions. With infrastructure growth that is fast and increasingly optimal, the integration of AI in e-Learning will also be easier to apply, so that it will have an impact on improving the quality of education in Indonesia.

\section{CONCLUSIONS AND SUGGESTIONS}

The era of globalization has a significant effect on the development sector, especially technology in Indonesia. Nowadays, technology and communication have a high level of correlation in everyday life. Technology is no longer a complementary device that is facultative but rather a primary need for humans and even solutions to overcome the central problems of a country. This information is clearly illustrated through the involvement of technology in the education system in Indonesia.

The arrival of e-Learning in 2003 marked the movement of the government to improve the education system in Indonesia. Until now e-Learning development has run consistently even though it has not reached the maximum point; so an escalation in technical terms is needed, such as integration with AI technology. The benefits of deep learning and its application are considered capable of meeting the growing needs of e-Learning systems. However, every idea of transition will be faced with fundamental consequences. Therefore, appropriate and effective handling is needed.

Infrastructure is not only intended for the system alone, but in the mentality of users in planning the industrial revolution 4.0. Educational institutions are required to improve the quality of humans as users of technology to be applied in the education system and not just focus on the provision of information and communication technology. This suggestion arises based on the essence of improving the quality of education not only in the sophistication of technology but also in the sophistication of educators and students in carrying out the educational process. The education sector in Indonesia is increasingly allowed to improve the quality of life of its population through collective adjustments and perfectly integrated systems.

\section{REFERENCES}

[1] Antonius Aditya, Hartanto dan Onno W. Purbo. (2002). ELearning berbasis PHP dan MySql. Elex Media Komputindo.

[2] A. Konar. (2005). Computational Intelligence: Principles, Techniques and Applications. Springer.

[3] Cross, J. A., Dublin, L., \& American Society for Training and Development. (2004). Implementing e-learning. Alexandria: American Society for Training \& Development.

[4] E. Turban. (1990). Decision Support and Expert Systems: Management Support Systems. Macmillan.

[5] Examples of Artificial Intelligence in Education - Current Applications. (1 September, 2017). Accessed July 27, 2019 from https://www.techemergence.com/examples-ofartificial-intelligence-in education/

[6] Gunardi, Setiono. (2016). Apa itu E-Learning? HarukaEdu Punya Produk Terbaiknya (26 Mei 2016). Accessed $\begin{array}{llll}\text { September } & 15, & 2019 & \text { from }\end{array}$ https://www.kompasiana.com/sutiono/apa-itu-e-learningharukaedu-punya-produkterbaiknya_5746860f729373dd1baa3c9e

[7] H. Rolston. (1988). Environmental Ethics: Duties to and Values in the Natural World. Bormann.

[8] Ismaila, Idris. (2012). Model and Algorithm in Artificial Immune System for Spam Detection. International Journal of Artificial Intelligence and Applications, vol. 4

[9] Jenkins, M., \& LTSN Generic Centre. (2003). LTSN generic centre e-learning series. York: Learning and Teaching Support Network. Josina. (n.d.).

[10] Survei: 87\% Perusahaan Indonesia Melirik Teknologi AI. Accessed September 28, 2019 from https://inet.detik.com/business/d-3431798/survei-87perusahaan-indonesia-melirik-teknologi-ai

[11] Kusumadewi, Sri. (2003). Artificial Intelligence (Teknik dan Aplikasinya). Graha Ilmu.

[12] Learning Language Online. (11 Januari 2018). Accessed August 18, 2019 from https://squline.com/indonesiamasuk-top-10-pertumbuhan-e-learning-di-seluruh-duniasquline-targetkan-kenaikan-25-dari-angka-pertumbuhanbisnis/ 
[13] Lukmana, Lukas. (2006). Dukungan Industri Software Dalam Implementasi E-Learning di Dunia Pendidikan (5 September 2006). Accessed September 8, 2019 from http://www.wahanakom.com/infotek/elearning.html

[14] Masie, E., Kelly, K., \& MASIE Center. (2000). Conversations with Kevin Kelly and Elliott Masie. VIDEO CASSETTE. Saratoga Springs, NY: MASIE Center Inc

[15] McCarthy, John (1960). Recrursive Functions of Symbolic Expressions and Their Computation by Machine. Communications of the ACM

[16] Menristekdikti Nasir: Indonesia Siap Menyambut Globalisasi Pendidikan dan Revolusi Industri ke-4 (n.d). Accessed August 8, 2019 from hhtps://www.ristekdikti.go.id/menristekdikti-nasirindonesia-siap-menyambut-globalisasi-pendidikan-danrevolusi-industri-ke-4/

[17] Number of internet users in Indonesia from 2015 to 2022 (in millions) - Statista.com. (n.d.). Accessed July 28, 2019fromhttps://www.statista.com/statistics/254456/numbe r-of-internet-users-in-indonesia/

[18] P.H. Winston and K.A. Prendergast. (1984). The AI Business, The Commercial. Uses of Artificial Intelligence. The MIT Press.
[19] Siahaan, Sudirman. (2002). E-Learning (Pembelajaran Elektronik) Sebagai Salah Satu Alternatif Kegiatan Pembelajaran. Jurnal Pendidikan dan Kebudayaan.

[20] Soekartawi (2003). Prospects and Challenges e-Learning: A Review. Paper presented at Academic Conference UPSI international, Tanjong Malim, 24-25 September 2003.

[21] Sulistyo-Basuki, L. (2007). IT and education, the case study of e-learning in Indonesia., Conference Paper disampaikan di Korea-ASEAN Academic Conference on Information Revolution and Cultural Integration in East Asia, Ho Chi Minh city, Vietnam, Januari 25-26, 2007.

[22] W. J. Teahan. (2010). Artificial Intelligence - Agents and Environments. Bookboon.

[23] Sutrisno. (2007). E-learning di Sekolah dan KTSP (11 Oktober 2007). Accessed September 11, 2019 fromhttps://pendidikannetwork.co.id.

[24] Wahono, Romi Satria. (2008). Definisi dan Komponen Elearning. Accessed September 11, 2019 from http://romisatriawahono.net/2008/01/23/meluruskansalahkaprah-tentang-e-learning. 